ks. Przemysław Kantyka, Jedność Kościoła a jedność $w$ wierze. Od ekumenizmu idealistycznego do ekumenizmu realistycznego?, [w:] O co chodzi w ekumenizmie? Czym jest

dialog? Podstawowe idee Vaticanum II pót wieku później, red. Marek Kita, Kraków 2015, s. 33-43.

DOI: http://dx.doi.org/10.15633/9788374384551.04

ks. Przemysław Kantyka

\title{
Jedność Kościoła a jedność w wierze. Od ekumenizmu idealistycznego do ekumenizmu realistycznego?
}

Jedność wyznawanej wiary powszechnie uważana jest za warunek konieczny do odbudowania widzialnej jedności Chrystusowego Kościoła. Samo jednak pytanie o potrzebny do osiągnięcia kształt i stopień uzgodnienia zagadnień doktrynalnych nie znajduje $\mathrm{w}$ chrześcijaństwie jako całości wspólnej odpowiedzi. Pomimo trudności na wielu płaszczyznach toczą się ekumeniczne dialogi doktrynalne mające za cel usunięcie przeszkód do jedności w postaci nieprzekraczalnych różnic w wierze. Tu od razu pojawia się pytanie o to, jak daleko może posunięta być różnorodność nie tylko życia kościelnego, ale sformułowania wiary, aby można było mówić o różnorodności pojednanej, czyli nieniosącej podziału.

Od lat trwający proces ekumenicznych uzgodnień uświadomił dialogującym stronom, że praca do wykonania jest o wiele większa i trudniejsza, niż się początkowo spodziewano, a wyniki dialogów ekumenicznych w niewielkim stopniu i nierychliwie przekładają się na odczuwalne zbliżenie kościelne. Ruch ekumeniczny przeszedł więc proces przechodzenia od ekumenicznego idealizmu do realizmu, lub po prostu - jak wolą inni - osiągnął nieuniknioną fazę dojrzałości. 


\section{Początkowy entuzjazm - ekumeniczny idealizm}

Kościół rzymskokatolicki zaangażował się w dialog ekumeniczny, realizując przełomową wizję Soboru Watykańskiego II zawartą w Dekrecie o ekumenizmie. Można - bez żadnej przesady - powiedzieć, że dialogi międzykościelne z udziałem Kościoła rzymskokatolickiego, zarówno dwustronne, jak i wielostronne, wręcz „wybuchły” po Vaticanum II z siłą tym większą, im bardziej do tego czasu wydawały się niemożliwe. Do Soboru bowiem odbywały się jedynie nieliczne, nieoficjalne rozmowy, nieangażujące autorytetu Kościołów ${ }^{1}$. W dobie posoborowej Ecclesia Romana zaangażowała się w kilkanaście dialogów doktrynalnych. Partnerami rzymskich katolików w dialogach dwustronnych stali się: prawosławni, Ormianie, Syryjczycy, Asyryjczycy, Koptowie, Erytrejczycy, Etiopczycy (starożytne Kościoły Wschodnie), anglikanie, luteranie, reformowani, metodyści, baptyści, uczniowie Chrystusa, zielonoświątkowcy, ewangelikalni i Adwentyści Dnia Siódmego².

Sam fakt rozpoczęcia i prowadzenia tych dialogów słusznie okrzyknięto dużym sukcesem, choć właściwie należy mówić o wielkim tchnieniu Ducha Świętego. Początkowy entuzjazm kazał wierzyć w szybkie doprowadzenie do zbliżenia Kościo-

1 Dialogi takie należały do inicjatyw quasi-prywatnych. Najbardziej znany jest wieloletni dialog francuskiego lazarysty ks. Portala (rzymskiego katolika) z angielskim lordem Halifaxem (anglikaninem), toczący się na przełomie XIX i XX stulecia pod patronatem abp. Malines (Mechelen) kard. Merciera.

2 Zob. S. C. Napiórkowski, Panorama dialogów doktrynalnych z udziałem Kościoła rzymskokatolickiego, [w:] S. C. Napiórkowski, S. J. Koza, P. Jaskóła, Na drogach do jedności, Lublin 1983, s. 22-79; K. Karski, Dialogi dwustronne Kościoła rzymskokatolickiego, „Studia i Dokumenty Ekumeniczne” 18 (2002) nr 1 (49), s. 9-50; Growth in Agreement. Reports and Agreed Statements of Ecumenical Conversations on a World Level, ed. H. Meyer, L.Vischer, Ramsey, New York-Geneva 1984; Growth in Agreement II. Reports and Agreed Statements of Ecumenical Conversations on a World Level 1982-1998, ed. J. Gros, H. Meyer, W. G. Rusch, GenevaGrand Rapids [Mi] 2000; Growth in Agreement III. International Dialogue Texts and Agreed Statements, 1998-2005, ed. J. Gros, T. F. Best, L. F. Fuchs, Geneva-Grand Rapids [Mi] 2007. 
łów, a nawet do usunięcia przyczyn podziałów chrześcijaństwa. Ostatnie czterdzieści lat pokazało, że droga do jedności jest długa i trudna, a wypracowywane w komisjach do spraw dialogu dokumenty nie przekładają się wprost na widzialną jedność Kościoła.

\section{Jedność Kościoła, a nie jednolitość}

W rozumieniu posoborowym jedność Kościoła nie zakłada uniformizacji wszystkich aspektów życia kościelnego, od doktryny począwszy, przez strukturę Kościoła i liturgię, na zwyczajach i strojach skończywszy. Właściwie postawione pytanie brzmi: jaki stopień uzgodnienia doktryny jest konieczny, jakie jej elementy muszą być absolutnie wspólne, jakie zaś mogą należeć do odmiennych ujęć teologicznych? Trzeba też określić, jaki model funkcjonowania Kościoła byłby najbardziej odpowiedni dla wyrażenia jedności bez jednolitości?

Modelem, który znajduje coraz większe uznanie w świecie dialogów ekumenicznych, szczególnie tych toczonych w ramach Komisji Wiara i Ustrój Światowej Rady Kościoła, jest model koinonii, zawierający w sobie odniesienie zarówno do komunii, jak i do wspólnoty. Pogląd ten znajduje szerokie odzwierciedlenie w najnowszym dokumencie eklezjologicznym ŚRK: Church - Towards a Common Vision?. Ponadto w rozważaniu różnych sposobów „bycia Kościołem” można przyjąć wykorzystanie „modeli” (typoi) lub ich elementów, które mogą być pomocne w odbudowaniu widzialnej, organicznej jedności Chrystusowego Kościoła. Po pierwsze, zakłada się różnorodność „tradycji kościelnych”, które przejawiają podstawową zgodność w wierze, doktrynie i strukturze niezbędnej dla misji, a jednocześnie posiadają właściwy dla siebie styl teologii, kultu, duchowości i dyscypliny. Dalej, możliwie jest szersze wykorzystanie kategorii „Kościołów siostrzanych”, wska-

3 World Council of Churches, The Church - Towards a Common Vision, Faith and Order Paper no. 214, Geneva 2013. 
zując na tradycyjne od czasów patrystycznych odnoszenie się do siebie Kościołów Rzymu i Konstantynopola, w XX zaś wieku na zastosowanie tej kategorii przez papieża Pawła VI do Kościoła anglikańskiego. Ponowne ustanowienie jedności pomiędzy podzielonymi tradycjami byłoby więc pojednaniem w rodzinie. Wymagałoby to jednak ze strony rzymskokatolickiej przeformułowania Noty Kongregacji Nauki Wiary ograniczającej możliwość stosowania kategorii „Kościołów siostrzanych”.

Innym wreszcie kierunkiem jest wskazanie na różnorodność rytów Kościołów Wschodnich i Orientalnych zjednoczonych z Rzymem. Kościoły mogłyby więc być postrzegane jako osobne ryty, pozostające wciąż jednak w komunii ze sobą i z biskupem Rzymu. Daje to możliwość zachowania własnego stylu pobożności i życia kościelnego bez zakładania jednak „wchłonięcia” jednych struktur przez drugie, lecz z akceptacją uprawnionej różnorodności, którą Kościół powinien chronić i zapewniać jej warunki do rozwoju. Powstaje jednocześnie pytanie o granice różnorodności oraz o ewentualną konieczność znalezienia nowych form episcopē, być może „zachodzących” na siebie.

\section{Dialog doktrynalny drogą do jedności wiary}

Niewątpliwie za podstawowe osiągnięcie ruchu ekumenicznego można uznać samo wzajemne zaakceptowanie siebie przez różne Kościoły, które widzą w sobie nie tylko partnerów dialogu, ale także wiernych przez chrzest wszczepionych w Chrystusa i Jego Kościół. Słynna już maksyma Karla Bartha: „My, chrześcijanie, wierzymy wprawdzie wciąż inaczej, ale nie w Innego", prowadzi nas w konsekwencji do uświadomienia stanu - wedle słów Jana Pawła II - faktycznie posiadanej, acz jeszcze nie doskonałej komunii pomiędzy Kościołami. Ewolucja wzajemnego nastawienia Kościołów do siebie jest także owocem konse-

4 Kongregacji Nauki Wiary, Nota w sprawie posługiwania się wyrażeniem „Kościoły siostrzane”, „Biuletyn KAI” 200 nr 51, s. 24-25. 
kwentnego dialogu ekumenicznego, prowadzonego pomimo trudności, jakie nieustannie się pojawiają.

Okres po II Soborze Watykańskim to czas, w którym ogromne dzieło dialogu ekumenicznego osiągało stopniowo swoją dojrzałość. Euforia lat posoborowych, kiedy dialogi doktrynalne pomiędzy Kościołem rzymskokatolickim a innymi Kościołami i Wspólnotami kościelnymi rozwijały się zarówno w wymiarze światowym, jak i lokalnym, ustąpiła miejsca przeświadczeniu o konieczności kontynuowania żmudnej pracy szukania porozumienia, niezależnie od niewielkiej liczby spektakularnych wydarzeń. Okazało się bowiem, że prace komisji teologicznych są trudniejsze i bardziej czasochłonne, niż można było przypuszczać, a opracowanie jednych kwestii czy nawet osiągnięcie w wielu aspektach konsensusu przynosi nowe problemy, bez których rozwiązania nie można jeszcze mówić o pełnej zgodności w wierze.

Wypracowane dokumenty dialogów teologicznych, pomimo swej doniosłej treści, zwykle nie są dobrze znane ani przez teologów, ani przez ogół wierzących ${ }^{5}$. Mało kto chce choć pokrótce zapoznać się z podstawowymi osiągnięciami dialogu doktrynalnego Kościoła rzymskokatolickiego z innymi Kościołami i Wspólnotami kościelnymi. Tymczasem dialogi te przyniosły wyraźny postęp na drodze uzgadniania doktryny. Efekty dialogów możemy zauważyć szczególnie w takich zagadnieniach teologicznych, jak nauka o Trójcy Świętej i Jezusie Chrystusie, nauka o usprawiedliwieniu, o chrzcie, o Eucharystii, o Kościele i posługiwaniach zakorzenionych w sukcesji apostolskiej, o autorytecie w Kościele - w tym o prymacie Biskupa Rzymu, o rzymskokatolickiej mariologii, wreszcie o zagadnieniach moralnych i etycznych ${ }^{6}$.

5 Zob. Recepcja - nowe zadania ekumenizmu, red. W. Hryniewicz, L. Górka, Lublin 1985.

6 Zob. P. Kantyka, Dialog ekumeniczny katolicko-protestancki-założenia, zakres, rezultaty, [w:] Ekumenizm w posoborowym pótwieczu. Sukcesy i trudności katolickiego zaangażowania na rzecz jedności chrześcijan, red. M. Składanowski, T. Syczewski (Teologia w Dialogu, 14), Lublin 2013, s. 29-50. 
Kategorią niezwykle pomocną w dialogu doktrynalnym, a niewystarczająco jeszcze wykorzystywaną jest przypomniana w Dekrecie o ekumenizmie zasada "hierarchii prawd" wiary. Przypomnijmy: chodzi nie o różny stopień ważności poszczególnych prawd wiary ani o stopień ich obowiązywalności, ale ich różne „powiązanie z zasadniczymi podstawami wiary chrześcijańskiej”. Kategoria „hierarchii prawd” znana w teologii katolickiej zaczyna być też wykorzystywana w dialogach ekumenicznych, szczególnie z Kościołami i Wspólnotami kościelnymi wyrosłymi z Reformacji ${ }^{8}$. Teologia prawosławna podchodzi do tej kategorii teologicznej raczej nieufnie.

Z pewnością dla nadania dialogowi ekumenicznemu nowego rozmachu i nowej energii potrzebne jest wypracowanie i - na ile to możliwe - zaakceptowanie przez wszystkie strony dialogu swoistego ethosu ekumenicznego. Kardynał Walter Kasper, poprzedni prefekt Papieskiej Rady ds. Jedności Chrześcijan, zaproponował następujący opis ethosu właściwego ekumenizmowi życia:

Zaniechanie jakiejkolwiek formy prozelityzmu otwartego lub utajonego, świadomość, że każda decyzja podjęta w naszym Kościele dotyczy równocześnie naszego partnera, leczenie ran naszej historii przez oczyszczenie pamięci, recepcja rezultatów dialogów dotychczas osiągniętych, a często za mało znanych?

\section{Co realnie dały dotychczasowe dialogi ekumeniczne?}

Celem dążeń ekumenicznych jest osiągnięcie widzialnej jedności Kościoła opartej na jedności w wierze. Jakie są więc

7 Dekret o ekumenizmie „Unitatis redintegratio”, [w:] Sobór Watykański II. Konstytucje, dekrety, deklaracje. Tekst polski. Nowe tłumaczenie, Poznań 2002, punkt 11.

8 Zob. S. Pawłowski, Zasada hierarchii prawd wiary. Studium ekumeniczno-dogmatyczne na podstawie najnowszej myśli teologicznej (1984-2003), Lublin 2004.

9 W. Kasper, Zaangażowanie ekumeniczne Kościoła katolickiego, „Studia i Dokumenty Ekumeniczne" 19 (2003) nr 1 (52), s. 31. 
konkretne owoce dialogu ekumenicznego? Co przyniósł on oprócz tomów zapisanego papieru, nad którymi pochylają się jedynie specjaliści? Co oprócz doświadczenia mozolnego trudu bez wyraźnych efektów? Przede wszystkim zauważyć należy, że dialog długo i cierpliwie prowadzony dał chrześcijanom możliwość wzajemnego spojrzenia na siebie jako na braci i siostry, w przyjaźni. Dał poczucie odpowiedzialności: problemów doktrynalnych nie można pominąć, lub ot tak, po prostu unieważnić. Byłby to „tani” ekumenizm, a nie prawdziwa jedność w wierze. Dialogi uświadomiły nam, jak trudna droga pozostaje jeszcze do przejścia; jednocześnie widzimy pierwsze owoce pojednania, co zachęca do bardziej wytrwałej pracy. Pozwoliły także na - powolne co prawda, ale jednak faktyczne - odkrywanie bogactwa zawartego w naszych teologicznych, liturgicznych i kanonicznych tradycjach. Można bez przesady powiedzieć, że dotychczas prowadzone dialogi pozwoliły wszystkim chrześcijanom wzrastać ku jedności i przyczyniły się do trwałej przemiany współczesnego Kościoła. Uświadomiły wreszcie, że nie sami i nie wyłącznie własnymi siłami sięgniemy po widzialną jedność Kościoła, gdyż ona jest darem Boga. Czy dialogi ekumeniczne dały za mało? Z pewnością - jeśli stan obecny mierzyć skalą oczekiwań i pragnień. Dały natomiast bardzo wiele, jeżeli weźmiemy pod uwagę wzajemne relacje poszczególnych wyznań w dobie rozpoczynania dialogu.

\section{Ekumenizm realistyczny - kapitulacja idei?}

Po latach dojrzewania ruchu ekumenicznego, po latach żmudnych dialogów doktrynalnych, po wydrukowaniu tysięcy stron teologicznych uzgodnien, wobec braku spektakularnych osiągnięć $\mathrm{w}$ postaci faktycznego zjednoczenia podzielonych chrześcijan wielu popada w zniechęcenie. Liczba odrębnych organizmów kościelnych zamiast ubywać, ciągle rośnie. Szczególnie po stronie protestanckiej obok zawieranych konkordii (jak 
np. Miśnieńska czy Leuenberska ${ }^{10}$ dających wspólnotę ołtarza i ambony wielu tradycyjnym Kościołom wywodzącym się z Reformacji, widać wciąż przyrastającą liczbę niezależnych organizmów kościelnych. Protestantyzm dzieli się nieustannie niejako przez pączkowanie. Przy tym szczególnie grupy należące do tzw. nurtu ewangelikalnego czy pentekostalnego ${ }^{11}$ dalekie są od jakiejkolwiek formy dialogu doktrynalnego czy nawet współpracy ekumenicznej w dziedzinie tzw. ekumenizmu praktycznego. Brak stałego kontaktu pomiędzy tymi grupami a innymi Kościołami wyznaniowymi uniemożliwia podejmowanie wysiłków na rzecz wspólnego świadectwa chrześcijan. Niestety trzeba przyznać, że dzieje się tak wszędzie tam, gdzie górę bierze mentalność sekciarska. Dla sprawiedliwości trzeba dodać, że i w łonie Kościoła katolickiego oraz innych Kościołów i Wspólnot istnieją grupy tradycjonalistyczne (zwane też integrystycznymi lub staroobrzędowymi), które odmawiają wszelkich form dialogu ekumenicznego, a tym samym odcinają się od samej możliwości podjęcia wspólnego świadectwa z innymi chrześcijanami.

Ogłaszane co jakiś czas cząstkowe postępy w teologicznym dialogu doktrynalnym, zwieńczone nawet porozumieniem czy międzykościelną deklaracją - jak w przypadku deklaracji w sprawie nauki o usprawiedliwieniu ${ }^{12}$ - nie stanowią wyraźnego wzmocnienia wspólnego przekazu chrześcijańskiego świadectwa. Istnieją wprawdzie przykłady wspólnego zabiera-

${ }^{10}$ Konkordia to jeden z opisywanych w literaturze ekumenicznej tzw. „modeli jedności”. Zob. S. C. Napiórkowski, Modele jedności, [w:] Ku chrześcijaństwu jutra. Wprowadzenie do ekumenizmu, red. W. Hryniewicz, J. S. Gajek, S. J. Koza, Lublin 1996, s. 479-503.

${ }_{11}$ Zob. M. Jopek, R. Porada, Zielonoświątkowcy, [w:] Ku chrześcijaństwu jutra. Wrowadzenie do ekumenizmu, dz. cyt., s. 206-212.

${ }^{12}$ Kirche und Rechtfertigung. Das Verständnis der Kirche im Licht der Rechtfertigung. Gemeinsame römisch-katholische/evangelisch-lutherische Kommission, Paderborn-Frankfurt am Main 1994; Kościót i usprawiedliwienie. Rozumienie Kościoła w świetle nauki o usprawiedliwieniu. Raport z trzeciej fazy Międzynarodowego Dialogu Luterańsko-Rzymskokatolickiego (1993), tłum. K. Karski, „Studia i Dokumenty Ekumeniczne" 11 (1995) 2, s. 43-138. 
nia głosu w sprawach społecznych przez Kościół rzymskokatolicki i Kościoły niekatolickie - by wymienić choćby wydane kilkakrotnie wspólne listy pasterskie niemieckich biskupów katolickich i ewangelickich ${ }^{13}$ oraz nieliczne wspólne wypowiedzi biskupów katolickich i zwierzchników Kościołów zrzeszonych w Polskiej Radzie Ekumenicznej ${ }^{14}$ - przyznać jednak trzeba, że coraz trudniej znaleźć chrześcijanom wspólny język w ważnych sprawach etycznych i moralnych, jakim muszą stawić czoła współczesne społeczeństwa.

Stosunek do życia przychodzącego i odchodzącego, a więc moralna i etyczna ocena aborcji i eutanazji; postrzeganie ludzkiej seksualności, a w tym ocena zachowań homoseksualnych czy stosowania sztucznej regulacji poczęć; moralna i etyczna ocena zagadnień związanych z inżynierią biomedyczną, w więc zapłodnienia pozaustrojowego (w tym: in vitro), manipulacji genetycznych, a nawet krzyżówek transgenicznych; wreszcie samo podejście do zagadnienia nierozerwalności związku małżeńskiego czy samego zdefiniowania małżeństwa jako związku osób o odmiennej płci - te zagadnienia żywo dziś dyskutowane wewnątrz społeczeństw nie mogą doczekać się spójnej, a co najważniejsze: wspólnej, oceny świata chrześcijańskiego. Podzielone chrześcijaństwo nie mówi tu jednym głosem. Łatwiej dziś osiągać pomiędzy chrześcijanami porozumienia w sprawach zastarzałych różnic doktrynalnych, niż wypracować wspólne stanowisko w jednej chociaż z wymienionych wyżej kwestii. Podzielone chrześcijaństwo nie jest w stanie dać czytelnego świadectwa, a jego głos jest tym słabszy, im bardziej zatomizowany. Linia podziału przebiega tu zasadniczo pomiędzy Kościołem rzymskoka-

${ }^{13}$ Zob. np. P. Kantyka, L'Église et la politique, [w:] Ökumenische Verantwortung der Kirchen am Beispiel Polens und der Schweiz, red. P. Jaskóła (Sympozja, 18), Opole 1997, s. 51-53.

${ }_{14}$ Zob. np. G. Polak, Aspekty ekumeniczne Roku Jubileuszowego 2000, „Studia i Dokumenty Ekumeniczne” 46 (2000) nr 2 (46), s. 129-133; Przesłanie zwierzchników Kościołów Chrześcijańskich do młodych. Gniezno Anno Domini 2000. „L'Osservatore Romano" wyd. pol. 5 (2000), s. 53. 
tolickim i Kościołami prawosławnymi z jednej strony, a Kościołami i Wspólnotami kościelnymi wyrosłymi z Reformacji z drugiej strony. Podział ten jest wszakże dalece uproszczony i prowizoryczny, bowiem w łonie protestantyzmu możemy znaleźć całe spektrum postaw i ocen moralnych i etycznych tego samego zagadnienia. Niejednokrotnie linia podziału przebiega też nie pomiędzy Kościołami, ale w łonie samych Kościołów.

Wymieniony zespół zagadnień nie oddziałuje wyłącznie na życie społeczne. Ma on dalekie reperkusje w życiu religijnym Wspólnot kościelnych, wprowadzając na forum dyskusji i praktyki np. zagadnienie święceń osób aktywnych homoseksualnie czy błogosławienia kościelnego par jednopłciowych.

Gdy więc dochodzi do sformułowania oceny i realistycznego określenia stopnia odzyskiwania jedności w podzielonym chrześcijaństwie, nie można wydać jednoznacznie pozytywnego czy jednoznacznie negatywnego orzeczenia. Albowiem wszędzie tam, gdzie wyznawcy Chrystusa dają świadectwo męczeństwa, wszędzie tam, gdzie chrześcijanie starają się przezwyciężyć dzielące ich różnice i są w stanie przekazać czytelny obraz jednej wiary i wynikających z niej nakazów i zakazów moralnych - mamy do czynienia ze wspólnym świadectwem o Chrystusie i zmierzanie w kierunku jedności. Natomiast wszędzie tam, gdzie chrześcijanie bardziej cenią własne - nieraz bardzo karkołomne - interpretacje Ewangelii niż zdrową naukę wiary i wynikające z niej nakazy i zakazy moralne, mamy do czynienia $\mathrm{z}$ antyświadectwem, niejednokrotnie zgorszeniem, oraz tendencjami do coraz głębszych podziałów.

\section{Podsumowanie}

Na zadane w tytule pytanie o przejście od ekumenizmu idealistycznego do realistycznego trzeba odpowiedzieć twierdząco. Takie przejście musiało się dokonać. Zetknięcie z rzeczywistością nie pozwoliło długo chodzić z głową w chmurach. Jednak podjęcie rzetelnej pracy nad zagadnieniami stanowiącymi 
treść wiary nie oznacza rezygnacji z ideału, lecz w prostej linii do niego dąży. Jest to droga długa i wyboista, ale dająca pewniejsze, bardziej stabilne podstawy jedności niż proklamacje niezakorzenione w rzeczywistym konsensie. Dekretowanie jedności przez władze kościelne mogłoby się kolejny raz skończyć tak, jak Unia Florencka, która nigdy naprawdę nie weszła w życie.

Obecny prefekt Papieskiej Rady ds. Jedności Chrześcijan kard. Kurt Koch porównał rozwój ruchu ekumenicznego do lotu samolotem. Gdy samolot startuje, wtedy odczuwalne jest wielkie przyspieszenie i towarzyszące mu emocje. Gdy zaś wejdzie w fazę spokojnego lotu na dużej wysokości, pasażerowie nie odczuwają już emocji ani przyspieszenia, mimo iż prędkość jest większa od tej przy starcie. Ruch ekumeniczny jest w fazie spokojnego, wydajnego lotu, choć bez wielkich emocji. Zdarzają się jednak niekiedy turbulencje - by kontynuować to porównanie - i wtedy „pasażerowie” odczuwają wstrząsy. Nieważne, jak długo i jak spokojnie będzie trwał lot, o ile zakończy się szczęśliwym lądowaniem. Tego właśnie życzymy ruchowi ekumenicznemu. 